\title{
Celebrity Capital of Actresses of Color: A Mixed Methods Study
}

\author{
Yulia Medvedeva1, Cynthia Frisby², Joseph Moore² \\ ${ }^{1}$ Zayed University, Dubai, UAE \\ ${ }^{2}$ University of Missouri, Columbia, MO, USA \\ Email: frisbyc@missouri.edu
}

How to cite this paper: Medvedeva, Y., Frisby, C., \& Moore, J. (2017). Celebrity Capital of Actresses of Color: A Mixed Methods Study. Advances in Journalism and Communication, 5, 183-203.

https://doi.org/10.4236/ajc.2017.53011

Received: June 27, 2017

Accepted: August 14, 2017

Published: August 17, 2017

Copyright (c) 2017 by authors and Scientific Research Publishing Inc. This work is licensed under the Creative Commons Attribution International License (CC BY 4.0).

http://creativecommons.org/licenses/by/4.0/

\begin{abstract}
Is colorism in Hollywood a problem? A pilot study was conducted on two actresses, dark-skinned actress Lupita Nyong'o who won Best Supporting Actress Oscar in 2014 for her portrayal of a slave Patsey in the 2013 movie " 12 Years a Slave," 2013, and light-skinned actress Halle Berry who won Best Actress Oscar in 2002 for her portrayal of a widow Leticia Musgrove in the 2001 movie "Monster's Ball." Data obtained from the mixed-methods design employed in the study found a significant difference in how often an actress' complexion was used in a news story and how they were described using the language of racial capital. Contrary to expectations set by understanding of the concept of colorism, darker-skinned Nyong'o's racial capital was stated in the news less prominently than the racial capital of lighter-skinned Berry. Actresses' celebrity capital and ways of conversion of capital is visualized in Venn diagrams.
\end{abstract}

\section{Keywords}

Colorism, Field Theory, Racial Capital, Celebrity Capital, Qualitative and Quantitative Content Analysis

\section{Introduction}

"If a Black woman is light-skinned with good hair and good features, then she's ["hot"]... But a dark-skinned girl with short hair can forget it. And if she has a big nose, then she should just be a nun. But if she has long hair and good features, then her skin color can be overlooked. Long hair really helps out those black ugly girls." Darryl, a working-class Black man, as quoted in The Color Complex Viola Davis, Gabrielle Union, and Lupita 
Nyong'o have all been praised for their talents and physical attractiveness, but because they are darker-skinned they have, at some point in time, all have been asked to discuss how colorism, or skin color discrimination, affected their experiences in Hollywood. These women along with other actors, such as Halle Berry and Vanessa Williams, have also had unique experiences in and out of the entertainment industry based on their skin color. The goal of the current research is to apply Bourdieu's filed theory into a study of celebrity colorism and racial capital by using both quantitative and qualitative methods of inquiry. What makes this research so crucial is that it provides evidence of societal stratification based on racial measures of skin tone within the entertainment industry.

Colorism is a persistent problem for people of color in the United States and is an extremely controversial issue. So much so that colorism has been the center of investigation for centuries. For instance, some African Americans in the U.S. have learned to judge, value, and discriminate on the basis of skin color the very people who belong to their own race. Some, if not most, African Americans make "cultural divisions" in their race based on differences in skin tone and ultimately will associate stereotypes with each grouped division. The largest, most controversial division among African Americans is between light skinned and dark skinned individuals. Conflicts between light-skinned and dark-skinned African Americans have been around since the beginning of Western slavery (Russell, Wilson, \& Hall, 1992). Some sociology and media scholars argue that the conditions African Americans faced during slavery were the factors that initiated the phenomenon of colorism (Hunter, 2007).

Historical research reveals Caucasian slave owners forced themselves upon African American slaves, creating the mulatto African American individualone who had lighter skin and finer, softer textured hair otherwise known as "good hair." People of color who were direct outcomes of forced miscegenation between slave owners and slaves resembled Europeans and were favored and treated better than the "African-looking" slave. This treatment and discrimination between lighter-skinned and darker-skinned slaves sparked a sense of envy inside the African American race, which in turn ultimately destroyed the unity within the African American slave community. It has been argued that this sense of envy has flourished throughout history.

\section{Project Purpose and Rationale}

It is important to know if modern media contribute to reinforcement of colorism by differentially treating people of different complexions. Thus we looked at the coverage of two Oscar-winning actresses of color, darker-skinned Lupita Nyong'o and biracial lighter-skinned Halle Berry, with the goal of testing for differences in coverage of their celebrity capital using both quantitative and qualitative content analysis. Oscar-winning actresses were chosen as a subject of study because they are visible in the media and may serve as role models for 
their audience. In addition, the coverage of Oscar winners tends to involve discussion of all elements of individuals' capital: cultural, symbolic, economic, and social. Finally, the concept of capital as explained in field theory was employed because it illuminates the resources used for social mobility, which is linked to the problem of colorism as a limiting factor of social mobility.

This paper continues with a review of literature on the concept of colorism, followed by the discussion of field theory and kinds of capital.

\section{Literature Review on Media and Skin Color}

There are several major explanations for the racial disparities in media coverage between blacks and whites with comparable skill and experience. The discrimination explanation asserts that media subtly discriminate against dark skinned individuals. The racial capital explanation describes that people tend to put less value on blacks' education and experience but more value on that of whites, or that blacks' skill levels and experience are actually lower (Tomaskovic-Devey, Zimmer, Stainback, Robinson, Taylor, \& McTague, 2006).

Recent studies on representations of skin color in media illustrate symbolic associations of colorism, portraying light-skinned characters as divine, strong, virtuous, and compassionate (Parameswaran \& Cardoza, 2009). At the same time, darker-skinned individuals have been depicted as violent, criminals, stupid, and of low socio-economic status. Literature on images of men and women in rap music videos also suggest that African American females often have Eurocentric features compared to African American males (Conrad, Dixon, \& Zhang, 2009). African American females tend to have straighter hair, thinner noses and lighter skin color. Just as skin color is symbolically affiliated with societal constructions of racial hierarchies, so has other physical features including hair (White, 2005). Media, therefore, have played a central role in helping define, construct, and maintain a color caste system born from the legacy of slavery in the Americas.

The most prominent public debate of whether skin color and skin tone affect audience perceptions was raised when Time magazine's June 20, 1994 cover exhibited a photo-illustration of O.J. Simpson's Los Angeles Police Department mug shot. The photo showed Simpson with darkened skin and darkened razor stubble (Barron, 1994; Van Riper, 1994). Critics argued that making Simpson's skin darker publicly cast him in the stereotypical image of the menacing black man and that this image could negatively affect a jury's perception of him (Kurtz, 1994; Van Riper, 1994).

African Americans with dark-colored skin have faced more discrimination in terms of negatively stereotyped media images than African Americans with light-colored skin, who have enjoyed more social favoritism in the media (Ducille, 1996; Neal \& Wilson, 1989). Whether Time magazine editors had racist intent or not, many Americans perceived the colored image to be a race code. Simpson's visage and ethnicity were exploited, his complexion manipulated, and his plight was recast as "An American Tragedy" to sensationalize the case and 
sell more copies of Time magazine (Lipsitz, 1997).

\subsection{Race and Success in the Society}

Skin color is highly correlated with other phenotypic features-eye color, hair texture, broadness of nose, and fullness of lips (Thompson \& Keith, 2001). European features are all accorded higher status both within and beyond the African American community. These European traits function along with color in complex ways to "shape opportunities, norms regarding attractiveness, selfconcept, and overall body image" (Thompson \& Keith, 2001: p. 340). Data obtained in the Thompson and Keith (2001) study also seem to suggest that women with more Caucasoid features are perceived as more attractive to the opposite sex and are more successful in their love lives than women with more Negroid features (Thompson \& Keith, 2001). Dark-skinned women, according to this study, are seen as occupying the bottom rung of the social ladder, being least marriageable, and having the fewest options for higher education and career advancement.

If having dark colored skin is perceived as negative, or American consciousness is biased against dark complexions, how do media images of different skin tones affect judgments and perceptions of talent and achievement? The answer to this question provides important implications for people of color and their success in life.

\subsection{Bourdieu's Field Theory}

Individual's successful functioning in the society and social mobility may be explored through accumulation of three forms of power: economic, cultural, and social capital (Bourdieu, 1986), which is one of the tenants of field theory. According to Bourdieu (1986), one's capital takes on the form of 1) economic capital, which manifests itself in property rights and may be turned into money; 2) cultural capital, which manifests itself in educational qualifications and skills, and 3) social capital, which manifests itself in social connections and depends on the size of one's network supported by kinship relationships, and by the amount of economic and cultural capital held by those to whom the person is connected (Bourdieu, 1986).

Further refinements of the structure of capital available to individuals also included symbolic capital, defined as "[i]nstitutionally recognized and legitimated authority and entitlement" (Pasco, 2003: p. 13). In addition, cultural capital is seen as being constituted by three elements: a) embodied capital that includes skills, knowledge and other bodily characteristics, b) objectified capital that includes material objects and goods that are produces by the individual and given to others, and c) institutional capital such as "[a]cademic qualifications, awards, professional certificates and credentials" (Pasco, 2003: p. 13).

Bourdieu (1986) noted that conversions of forms of capital from one into another are instrumental for the reproduction of one's capital. For example, so- 
cial capital is developed by investment of other forms of capital (Portes, 1998) through the means of one's network that can be used for obtaining "material or symbolic profits" (Bourdieu, 1986: p. 249). At the same time, cultural and social capital may be converted into economic capital (Bourdieu, 1986). It is important to convert forms of capital that have the lowest costs of conversion and the lowest losses during the process (Bourdieu, 1986). Minorities specifically have to find effective ways of converting available capital to achieve institutional recognitions such as the Pulitzer Prize in the field of journalism (Volz \& Lee, 2013a; 2013b).

\subsection{Racial Capital}

As noted earlier, skin tone determines one's chances of success in life. Glenn (2008) notes that while men are evaluated by their education and wealth, among other elements of human capital, all that is required from women is physical attractiveness, which in many cultures is associated with light skin tone. This warrants the inclusion of racial capital into the array of kinds of capital available to an individual.

Molina-Guzmán (2013) used the term "racial capital" when she explored the role of skin tone in entertainment industry. Racial capital is "a heuristic device to think through the ways ethnic and racial minority actors and the roles they perform are culturally commodified and accumulate cultural capital" (MolinaGuzmán, 2013: p. 215). Molina-Guzmán (2013) argues that Black Latina/o actors commodity their looks because movie industry is looking for racial minorities that are globally relevant.

McLoughlin (2013) writes:

Bourdieu (1991) refers to 'cultural capital' as the sum of valued material and symbolic goods, including knowledge, social and physical characteristics, and practical behavioural dispositions. As we will see, whiteness as a form of 'cultural capital' is not merely related to skin colour, but is culturally and historically constructed (p. 17).

As we can see, here racial and cultural capital are conflated together. In addition, Hunter (2004: p. 31) states that woman's beauty is her social capital, which is converted into other types of human capital. Racial capital is also seen as identity (Molina-Guzmán, 2013; Rockquemore \& Brunsma, 2004: p. 116).

According to the racial capital theory, resources embedded in our social networks can be used for occupational success. Several sociological theorists have created definitions of social capital (Bourdieu, 1986; Portes 1998). Portes' (1998) defines racial capital as the ability to secure benefits through one's membership in social networks. Portes' theory emphasizes that the status of an individual's contact affects their ability to use social networks to increase their status attainment. In other words, contacts with higher occupational prestige can lead to an increased occupational prestige for the individual. Several studies support this theory (Bridges \& Villemez, 1986; Braddock \& McPartland, 1987; Marsden \& 
Hurlbert, 1988). This definition is helpful because it highlights the significance of the ability to secure benefits. Just having multiple resources in the network is not enough; one must have the ability to secure benefits from those resources. For example, having a large network of ties is not helpful if none of them will help you find work.

Theories of racial capital can be used to clarify several aspects of the valuation of nonwhiteness. For example, from the lens of racial capital, we can perhaps illustrate the reasons that nonwhiteness has value to white people and predominantly white institutions. That is, racial capital provides an understanding of the way that racial value is transferred through interaction and affiliation. These ideas then provide the basis for understanding how the media frame and cover entertainers of color. That is, the study will explore the question "who reaps value from racial capital?"

The theoretical framework of racial capital provides insight into the reasons that media value particular racial identities and seek affiliations with individuals with those identities. The value acquired through such affiliations is part of the calculus that assigns worth to racial identity. And ultimately the fact that race is valued in this way is the foundation for the conversion of race into a commodity. Consequently, according to the theory, it is hypothesized that lighter skinned people are more likely to do well in the entertainment industry and obtain more media coverage because they possess more cultural capital.

Despite evidence that racial capital is a fluid concept, it is a valuable element in the framework of human capital. Following Molina-Guzmán (2013) in her study of how Black Latina actors and actresses are employing their racial capital, the present study will also explore media representations of capital of Hollywood actresses of color due to the visibility in the media they achieve when nominated for the Oscar award, which we treat as a instance of symbolic capital. Such study is further warranted by Driessens' (2013) argument about the utility of Bourdieu's filed theory in the study of celebrity capital.

The final portion of this literature review overviews issues associated with actors of color who received an Oscar.

\subsection{The Role of Social Capital in Racial Differences in Actor Success}

People of color have always been on the margins of Hollywood. Recognition for the narratives and films that critically engage the lives and histories of people of color have consistently been overlooked. Oscar nominations and nods have gone to Hattie McDaniel, Sidney Poitier, Denzel Washington, Halle Berry, and Jamie Foxx have been heralded in the media as examples of racial progress in Hollywood, allegedly highlighting an industry that seems to be moving away from racial exclusion and getting closer toward ideals of racial diversity. It is important to note that Halle Berry, the daughter of a white mother and a black father, was the first African American model for cosmetics company Revlon the early 1990s. However, for many black women Berry was not a true representation of the 
African American female: They felt that the inclusion of Berry in the Revlon ad was just the advertiser's way of using a "safe" black image in their ad.

Yet, if we look closer at the idea of diversity in Hollywood, one might find that complexion and skin tone of the faces in Hollywood play a huge role in who gets an Oscar nod and who does not. With limited exception, the Academy has awarded actors of color who played roles that perpetuate racial stereotypes. Hattie McDaniel, for example, was the first African American to win an Oscar for her portrayal of a mammy in "Gone with the Wind." Comedienne Mo'Nique won "Best Supporting Actress" for her performance as an abusive and neglectful mother in "Precious," while Denzel Washington took the "Best Male Performance" for his role as the crooked LAPD cop in "Training Day." These characters perpetuated established stereotypes Hollywood gatekeepers are more than willing to cast and, to deflect allegations of racism, award with Oscars to prop up a superficial notion of diversity.

Academy Award winner Lupita Nyong'o from "12 Years a Slave" is an actor of color who, for the first time in mainstream theatres, vividly exposed her talent as well as Hollywood and the media's obsession with skin tone and women of color. Nyong'o embodies the kind of black women Hollywood has not only marginalized, but also seems to disparaged. Unlike Halle Berry, Nyong'o's skin tone and blackness cannot be blurred or avoided, and nor blunted by a perpetuation of white beauty.

What we find often is that Hollywood tends to highlight and honor black women whose aesthetic beauty aligns with the white beauty ideal and standard (Dion, Berscheid, \& Walster, 1972). Images in the media tend to send a clear message that the image of blackness appearing in mainstream theatres and Oscars' stages is shaped by whites. In Hollywood, Nyong'o's blackness, as she so eloquently stated, "is an obstacle for her to overcome," which pre-empted and sidelined the careers of so many talented performers before her. Her beauty, body and blackness are affronts to both the structural colorism and racism in Hollywood.

As noted earlier, racial capital may be viewed as a part of cultural capital or as a part of social capital. Inclusion of race and racial capital as variables in the study of media coverage of celebrity introduces difficulties in classifying it. This, in turn, presents difficulties for a study employing quantitative content analysis, which is needed to establish the causal relationships between actors' skin tone and the nature of their coverage in the media. Thus the current study is a pilot study on a sample of two actresses from a larger sample of 14 actors and actresses who ever won Oscar up to date.

This study will test aspects of racial, social, cultural, symbolic and economic capital explanation by asking two research questions:

RQ1: How did the coverage of various kinds of celebrity capital differ between celebrities of color with dark skin tone and celebrities of color with light skin tone? 
RQ2: How did the coverage manifest the ways actresses of color converted the kinds of celebrity capital they possess into the kinds of capital they did not initially have?

The goal of this study was to apply filed theory to a study of capital possessed by celebrities using both quantitative and qualitative methods of inquiry. The use of quantitative method was warranted by the goal of establishing a causal relationship between the celebrity's skin tone and the volume of coverage of their capital. Qualitative analysis was warranted by the goal of understanding the nuances in differences in coverage of celebrities' capital.

Before conducting a larger scale project exploring celebrity capital of all Oscar winners of color, 7 male and 7 female actors, a pilot study on the samples of two actresses was conducted with the goal to test the mixed methods design. This pilot study focused on two actresses, dark-skinned actress Lupita Nyong'o who won Best Supporting Actress Oscar in 2014 for her portrayal of a slave Patsey in the 2013 movie "12 Years a Slave," 2013, and light-skinned actress Halle Berry who won Best Actress Oscar in 2002 for her portrayal of a widow Leticia Musgrove in the 2001 movie "Monster's Ball." The current manuscript reports the results of this pilot study, which are preceded by the explanation of the study's methodology.

\section{Method}

\subsection{Sample}

To obtain the sample, news database Factiva was searched for the name of the actress in quotation marks, the name of the movie in quotation marks and the word "Oscar" over a time period of two weeks before and two weeks after the televised Academy Awards ceremony. Based on a careful review of published studies on celebrities, we chose to follow similar data collection procedures employed in those studies, therefore we chose to use the database as well. The search was narrowed down within major news and business publications in the U.S. and filtered by the "Arts/Entertainment" category.

A-priory analysis was run in $G^{\star}$ Power program (Faul, Erdfelder, Lang, \& Buchner, 2007) to determine the sample size for two-tailed t-tests that would compare differences between the two groups with effect sizes anticipated to be moderate. The analysis revealed that at least 128 news stories were needed to detect the differences in coverage of two actresses if such differences existed. The sample yielded 183 stories, 100 of which mentioned Lupita Nyong'o, and 83 mentioned Halle Berry.

\subsection{Quantitative Analysis}

Quantitative content analysis was employed at the stage of quantitative data gathering. For the purposes of quantitative coding, actress was a unit of analysis. Each article was coded for actresses' racial, cultural, economic, social, and symbolic capital. Only paragraphs that mentioned the actress by name or contained 
the pronoun "she" referring to the actress were coded in every story. Since coding was interpretive and required coding for frequencies of occurrence of various elements of capital, coding as conducted sentence by sentence to make tracking of eligible cases easier for the coder. A coding sheet for each story was printed out, and the coder recorded the number of the sentence that mentioned the name of the actress and filled in all the relevant cells. The coder then summed up the number of coded instances in the "Total" line of the coding sheet, and this total reflecting the number of instances of each kind of capital per story was then transferred to the dataset in which each line was devoted to one actress and one news story.

\subsubsection{Racial Capital}

Racial capital was coded as a number of references to the actress' a) race defined as skin tone, facial features, and hair, b) ethnicity defined as the culture actress belongs to such as "African American," "Kenyan," or "Mexican-Kenyan," and as c) cross-cultural appeal, defined as suggestions that people of different cultures and skin tones can relate to the actress.

\subsubsection{Cultural Capital}

Cultural capital was operationalized as actress' skills, characteristics and traits of character that are a part of her body and personality, such as knowledge, skills, talent, charm, elegance, ability to dance or ride a horse.

\subsubsection{Symbolic Capital}

Symbolic capital included instances of stating that the actress won the Oscar or any other award and excluded mentions of the actress being nominated for the Oscar and other awards.

\subsubsection{Economic Capital}

Economic capital of the actress included mentions of actress' salary, property, contracts with commercial entities (e.g., being a spokesperson for a cosmetic company), wearing expensive gowns or owning any other physical objects that can be sold to gain money. This also included instances of linking the actress' participation in the movie's cast with movie's financial success.

\subsubsection{Social Capital}

Social capital included references to people who are linked to the actress either by the actress herself in direct or indirect speech by other source in the story or by a journalist. This included persons mentioned by name and by profession and could include family, friends, crew, other actors of color, historic figures and fictional characters of color, as well as ordinary people of color.

\subsubsection{Conversion of Capital}

Conversion of capital was operationalized as an instance of mentioning that the actress used the resources (elements of human capital) she already had to obtain the resources she did not have. The coder recorded the kind of capital used for 
conversion in once cell and the kind of capital obtained in conversion in another cell. This information was later used to track instances of conversion for qualitative analysis. Examples of conversion included sentences such as: "Nyong'o won the best supporting actress Oscar for her shattering performance in ' 12 years a slave'." The codebook instructed to ignore cases stating that actress won the Oscar for the supporting role, as in the following example:

Nyong'o had not even graduated from the Yale School of Drama when she got the best supporting actress-winning role of Patsey in "12 Years a Slave", her first film.

In cases like this it is unclear what kind of resource or capital did the actress use to obtain symbolic capital, while "shuttering performance" in the previous example points to cultural capital.

The obtained quantitative data was analyzed using two-tailed t-test in SPSS Version 21 to compare if samples devoted to the two actresses had differences in how they described actresses' kinds of capital. These data was also used to construct maps of actresses' capital with the help of Venn diagrams (see Figure 1 for Nyong'o's capital and Figure 2 for Berry's capital in Appendix A). The size of the circle reflects the number of instances a kind of capital was mentioned, and overlapping areas and arrows suggest the conversion of capital from one kind into another.

\subsection{Qualitative Analysis}

At the stage of qualitative analysis, instances addressing kinds of capital and conversion of capital were tracked down in individual stories and analyzed with

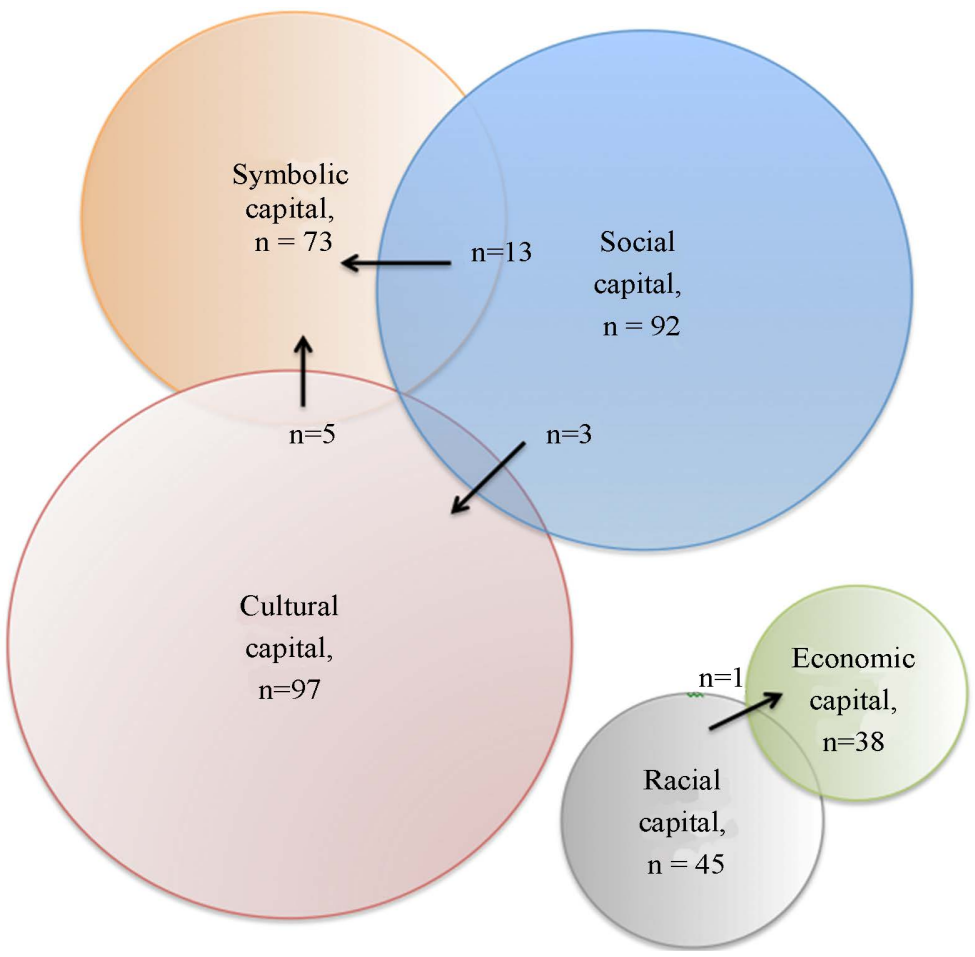

Figure 1. Lupita Nyong'o's celebrity capital. 


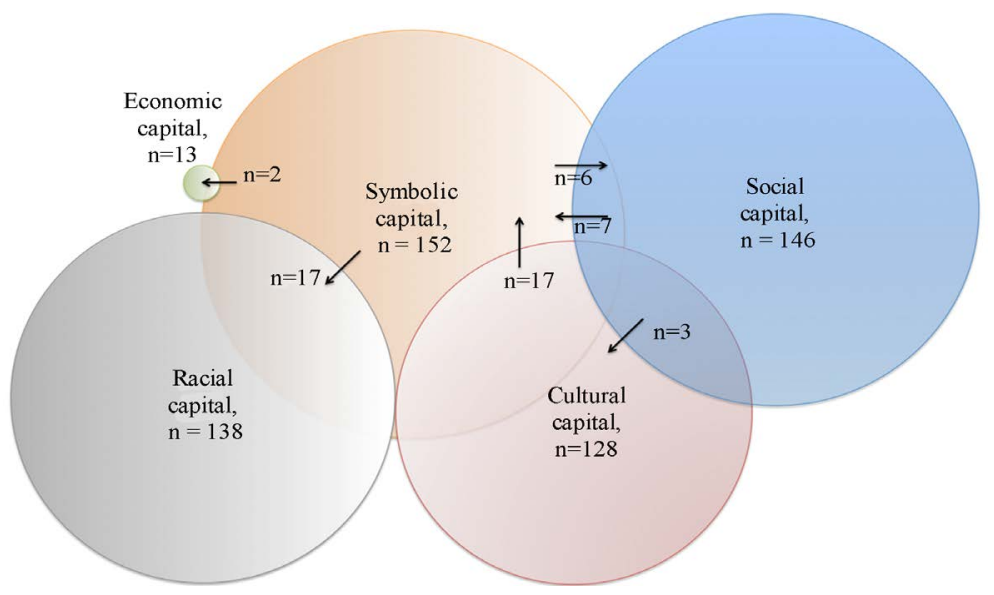

Figure 2. Halle Berry's celebrity capital.

the goal of explaining what kind of capital did the actress possess and how exactly did the actress benefit from the conversion of capital. In addition, during the quantitative coding notes were taken to document major ideas about coded news story to provide context to the statistical data. Constant comparative method of grounded theory (Strauss \& Corbin, 1998) was used to analyze the resulting data. Notes taken during quantitative coding and relevant paragraphs in news stories were analyzed using procedures of open and axial and coding. At the first round of reading, handwritten notes and relevant paragraphs were read in their entirety and some notes about first impressions from reading were made. At the second round of reading, the researcher took note of specific examples of discussing celebrity capital that seemed to standout as well as examples that seemed to be typical of the coverage in the sample. After the second reading, first draft of results was written summarizing major trends in coverage of every kind of actresses' capital were summarized and united with results of statistical analysis in the results section. Finally, taking into account major trends identified in statistical analysis, stories in the sample were read again to verify the preliminary findings and to take for additional context for the findings of statistical analysis.

In the next section, statistically significant results are reported together with raw frequencies yielded by data in the context of findings arrived at through the constant comparative method of data analysis. Findings are then discussed in the context of existing literature in the discussion section. The paper concludes with a summary of implications for future research that were identified during the work on this project.

\section{Results}

\subsection{Coverage of Kinds of Celebrity Capital}

RQ1 enquired about differences in the coverage of kinds of celebrity capital possessed by celebrities of color with dark skin tone and celebrities of color with light skin tone. 


\subsubsection{Racial Capital}

An independent-samples t-test was conducted to compare the use of race to address racial capital of Lupita Nyong'o and Halle Berry. There was a significant difference in the scores for dark-skinned actress Lupita Nyong'o $(M=0.06, S D=$ $0.278)$ and light-skinned actress Halle Berry $(M=1.30, S D=2.546) ; t(181)=$ $-4.843, p<0.001$. These results suggest that actress' complexion did indeed have an effect on how often they were described using the language of race. Specifically, our results suggest that Halle Berry, a daughter or a white mother and black father, was more often described as black than was Lupita Nyong'o, a dark-skinned Kenyan.

In terms of raw percentages of coverage, Nyong'o racial capital was addressed in terms of her race only in $13.3 \%(n=6)$ of cases. Nyong'o racial capital was defined in terms of her ethnicity-Mexico-born, Nigeria-raised-in $80 \%(n=36)$ of cases. It is worth noting that these two attributes were coded as two different cases because in some rare cases journalists omitted the fact that she was born in Mexico. Finally, references to Nyong'o cross-cultural appeal were made in $6.3 \%$ $(n=3)$ of cases.

One news story clarified that Nyong'o left Mexico with her parents when she has not even turned 1 year old, but for some reason many journalists chose to describe her heritage as "born in Mexico, raised in Kenya" or in a similar manner suggesting that Mexico is an important part of her heritage. This was probably one of the ways to convey her worldliness, especially when it was coupled with information that Nyong'o is American-educated-she attended Yale School of Drama and was living in New York at the time of coverage.

In the case of Berry's racial capital, she was addressed in racial terms, most often as a black actress or woman or as actress or woman of color, in $78.3 \%$ ( $n=$ 108) of cases. Berry's racial capital was defined in terms of her ethnicity (i.e., as “African American") in $21.7 \%(n=30)$ of cases. Berry's cross-cultural appeal was never mentioned. On the contrary, several stories described her experiencing racism as in the example below:

Despite her commercial and critical success, Halle Berry says she has had several encounters with racism during her film career. "What's hardest for me to swallow is when there is a love story, say, with a really high-profile male star, and there's no reason I can't play the part," Berry tells The New York Times. "They say, 'Oh, we love Halle, we just don't want to go black with this part."”

An explanation of why Berry was seen as a black woman originates from the sample. As The New York Times feature about Berry states:

Ms. Berry is the daughter of a white mother and a black father, but that distinction is lost on Hollywood. "Some executive explained it to me by talking about milk," [Berry's manager] Mr. Cirrincione says. "They said milk is milk until you add a little Hershey. It doesn't matter if you add a little Her- 
shey or a lot."

An article published in St. Louis Post-Dispatch clarified the issue in the following way:

Berry (nominated for best actress for "Monster's Ball") recounts how her mother told her to embrace her biracial heritage. "She knew that in America, you're not half black and half white, you're black and that is how I would be perceived, and I would be discriminated against as a black woman."

The coverage of overall racial capital (the total number of expressions via mentions of race, ethnicity, and worldliness) of the two actresses also showed statistically significant difference in the scores for Lupita Nyong'o $(M=0.45, S D$ $=0.925)$ and for Halle Berry $(M=1.66, S D=2.711) ; t(181)=-4.191, p<0.001$. These results suggest that actress' complexion overall had an effect on how often their racial capital was mentioned in news stories, though in a counter-intuitive direction. Nyong'o's racial capital was referred to less often in comparison to Berry.

\subsubsection{Symbolic Capital}

An independent-samples t-test was conducted to compare how often symbolic capital of Lupita Nyong'o and Halle Berry were addressed. There was a significant difference in the scores for Nyong'o $(M=0.73, S D=1.278)$ and for Berry $(M=1.83, S D=1.752) ; t(181)=-4.908, p<0.001$. These results suggest that stories devoted to Halle Berry mentioned Oscar and other awards she received more often than did stories devoted to Lupita Nyong'o.

\subsubsection{Cultural Capital}

An independent-samples t-test revealed no significant differences between the coverage of cultural capital of the two actresses.

It is worth noting that cultural capital of Nyong'o was mentioned the most times in comparison to other kinds of capital she possessed. In contrast, the number of references to Berry's cultural capital $(n=128)$ was lagging behind the number of references to her symbolic $(n=152)$, social $(n=146)$, and racial $(n=$ 138 ) capital. Judging by the raw frequencies allows concluding that Nyong'o artistic talents seemed to overshadow the other kinds of resources she had, while Berry's artistic talents were in a way belittled in comparison to her other resources. In addition, Nyong'o was saluted for her great talent in acting and as being poised and elegant, Berry's performance in the movie that won her and Oscar was described a surprise. Also covered was the fact that Berry participated in a sex scene in this movie and went topless in the movie "Swordfish," which is also discussed as a part of her embodied capital. This is how the topic was addressed in one feature story:

"I told Joel that I didn't want to go topless, and he listened to my reasons and told me to go ahead anyway, and I did," she [Berry] says. [...]. Had it 
not been for her accident or her breast-baring scene in "Swordfish," Ms. Berry could not have handled the raw lovemaking scene with Billy Bob Thornton in "Monster's Ball," she says.

Social capital. No statistically significant differences were detected in the volume of cases when actresses' social capital was mentioned.

Instances of social capital were mostly recorded in actresses' acceptance speeches and interviews. This definitely had an effect on the structure of actresses' social capital manifested in news stories. Nyong'o thanked the spirit of the real-life person she portrayed in the movie, a slave Patsey. She also thanked the movie's director Steve McQueen, who is black, and her co-star Chiwetel Ejiofor, who is also black. Another co-star she thanked and called "her rock" was a white actor Michael Fassbender. Nyong'o also thanked her family and school as members of her social network. Nyong'o was also said to be inspired to come into acting by the performance of the back actress Whoopi Goldberg. Overall, Nyong'o's social capital seemed to be constituted mostly of people of color. Support for her seemed to come from different sources and even epochs, and she didn't even meet in person some of the people who inspired her: Goldberg and Patsey.

While Nyong'o's acceptance speech was saluted in the news as exemplary, years earlier several news articles ridiculed Berry for mentioning a long list of people who led her to receiving her Oscar. Berry's social network also seemed to be diverse and included both white people and people of color. Journalists occasionally linked Berry's name with the director who had the courage to give her a first role and her manager. Several stories stated that connections with white players in the industry were crucial for Berry's success:

Though she has experienced racism, she has won the support of some of the most influential white men in the industry, including Warren Beatty and the producer Joel Silver.

Just like Nyong'o, Berry was said to draw her inspiration from talented actresses of color such as Dorothy Dandridge, whom she also portrayed in a movie.

\subsubsection{Economic Capital}

Analysis of data on overall economic capital did not yield statistically significant results. Yet an independent-samples t-test on one element of economic capital constituted by mentions of actresses' salaries and other materials goods they have access to, returned a significant difference in the scores for Lupita Nyong'o $(M=0.38, S D=1.153)$ and for Halle Berry $(M=0.08, S D=0.389) ; t(181)=$ $-2.233, p=0.027$. These results suggest that Nyong'o was portrayed as enjoying more material goods than did Berry.

Interestingly, only one reference to Nyong'o's economic capital concerned her honorariums. All other references addressed the designer gowns she wore during her appearances in public. On the contrary, references to Berry's economic 
capital were much more diverse. Seven references in total referred to her salary and designer outfits, and six more references described how financially successful are the movies featuring her.

\subsection{Conversion of Capital}

RQ2 asked about the ways new coverage manifested how actresses of color converted celebrity capital they possess into the kinds of capital they did not have.

\subsubsection{Conversion of Racial Capital into Economic Capital}

In terms of conversion of racial capital, only one such conversion was recorded in Nyong'o's sample. This instance occurred in a fashion article in New York Daily News:

At the Hollywood Film Awards, Nyong'o shone like new money in a mustard-yellow sheath by J. Mendel. [Fashion writer Teri] Agins says the look showed the actress' typical boldness with hues. "The fashion industry loves that she can wear color," she says. "If you're a designer and someone wears a dress of yours in a particular color, people remember it." Nyong'o's dark skin means she can play with color in ways that people with light skin can't. "Her skin is a perfect canvas; you can put anything against it," says Agins.

This case qualified as a conversion of racial capital into economic capital: Nyong'o's ability to wear color secured her designer outfits that other actresses could not were against their lighter skin. Notably, as was mentioned earlier, economic capital of Nyong'o was expressed mostly as her appearances in designer gowns, not her salary from acting in movies.

No conversion of racial capital into economic capital was recorded in Berry's case, which serves as a suggestion of how much of an obstacle was her skin color.

\subsubsection{Conversion of Cultural Capital into Symbolic Capital}

In 5 instances journalists explained what for Nyong'o received her Oscar as well as other awards due to her excellent performance. In the sample devoted to Berry, a conversion of cultural capital into symbolic capital was stated 17 times in the same manner. It is worth noting that both actresses were figured in roles written specifically for black actresses. In a way, it was not only their talent, but also their race that was involved in obtaining the Oscar, the symbolic capital.

\subsubsection{Conversion of Social Capital into Cultural Capital}

Both Nyong'o's and Berry's samples had 3 instances conveying that these actresses converted their social capital into cultural capital. More specifically, these conversions took a form of an actress seeing another actress of color as inspiration to continue career in acting. For Nyong'o, such actress was Whoopi Goldberg, and for Berry, it was Dorothy Dandridge.

\subsubsection{Conversion of Social Capital into Symbolic Capital}

Stories about both actresses contained references to the fact that they drew on 
their social network to reach the achievements that brought them an Oscar or another award. In Nyong'o case, 13 news stories suggested that she was thankful to at least one person for making the award possible. In Berry's case, 7 news stories had such suggestion. Interestingly, for Nyong'o this conversion looked mostly as her thanking other people in her acceptance speech, while for Berry this surfaced in statements of how hard it was for her to get the role that brought her an Oscar. The following example illustrates how the persistence of Berry's manager Vincent Cirrincione helped her secure the role of Leticia Musgrove in “Monster's Ball":

Of course, as Mr. Cirrincione points out, "Nobody thought she was right for 'Monster's Ball,' either," including the movie's director, Marc Forster, a Swiss. "I got aggressive, got Marc's number and kept him talking for 15 or 20 minutes," Mr. Cirrincione recalls. "I don't think I'm getting to him, so I tell him it'll get a lot of attention if she's in it because people will think she can't do it." Mr. Forster agreed to meet Ms. Berry.

Importantly, Cirrincione's goal in this case was not in persuading the director that the black actress is suitable for the role-the role was initially written for a black actress-this time the director did not see Berry in the role of a black single mother who works as a waitress because Berry was too beautiful for the role.

\subsubsection{Conversion of Symbolic Capital into Racial Capital}

Interestingly, Berry's sample provided evidence of 17 references suggesting that her Oscar will benefit people of color in general and actresses of color in particular. It is important to note that 6 more references conveyed the meaning that Berry's Oscar is devoted to deserving actresses of color who inspired her, and thus Berry is giving back to her social capital by receiving the Oscar as symbolic capital. This finding suggests that by winning an Oscar Berry not only got something for herself, but managed to convert her symbolic capital into benefits for people of her ethnicity.

While Nyong'o probably implied the same meaning in her acceptance speech, such instances as the following did not quality to be coded as a conversion of symbolic capital into racial capital due to their vagueness:

"Every time I look down at this golden statue, may it remind me and every little child that no matter where you're from, your dreams are valid," Nyong'o said between tears.

It is important to note that this type of conversion-conversion of symbolic capital into racial capital-also exposed the difficulty in separating instances of racial capital from instances of social capital during the coding process. This is most probably due to the fact that racial capital is in fact an attribute of social capital.

\subsubsection{Conversion of Symbolic Capital into Economic Capital}

Finally, two cases in Berry's sample suggested that the Oscar for Best Actress will 
have a positive effect on Berry's pay an on "Monster's Ball” box-office.

\section{Discussion}

This project specifically sought to examine kinds of capital employed by people of color in the entertainment industry and how it is used in news coverage. Based on prior research, we expected that actresses' racial capital and colorism existing in society will affect the amount and quality of media attention actors of color receiving. We expected that differences in skin tone account for the inequality and biased media attention and news coverage between entertainers of different skin tones. What was found was that in terms of darker skin tone, actress' ethnicity could possibly serve as a concealed way to convey her skin tone.

We found a significant difference in how often an actress' complexion was used in a story and described using the language of racial capital, though this finding was counter-intuitive to our expectations guided by the notion of colorism. More specifically, darker-skinned actress Lupita Nyong'o's race, ethnicity, and cross-cultural appeal were discussed less often than race and ethnicity of biracial Halle Berry. In addition, when the number of references to the actresses' race was analyzed, these findings held again. While dark-skinned Nyong'o was hardly ever addressed as a black actress, half-white Berry was constantly addressed as either Black of African American. It was noted in previous research on advertising that Halle Berry is not perceived as a black woman by black female audiences (Arogundade, 2014; Bradt. 2010). We consider several possibilities in interpreting these results. On one hand, Nyong'o's ethnicity as Kenyan may have served as a concealed way to convey her skin tone. On the other hand, not only skin tone might be a factor in the news coverage of actors of color, but also the time. Berry was the first woman of color to receive an Oscar for Best Actress, and journalists might have thought it was important to identify her race and ethnicity. It may well be that Berry's Oscar win in 2002 indeed opened the door for other black actresses, and by the time Nyong'o won her Oscar in 2014, a black female Oscar winner was not a novelty anymore. That might be the reason why the media made less nods toward her dark skin tone. In addition, it may well be that Nyong'o's coverage was effected by what Molina-Guzmán (2013) documented in the study of Black Latina actresses: As a person of color, Nyong'o was appealing to people in multicultural audiences, and the media were recognizing it by omitting the emphasis on her race.

That is why future studies should incorporate time as a possible predictor of coverage of celebrity capital. Such research designs might help scholars identify historical shits in media representation of celebrities of color.

Our findings also provided support to our intention to analyze the coverage of all acting Oscar winners of color. Both Nyong'o and Berry might prove to be outliers in their cohort of Oscar-winning actors of color. We suggest rating actors by their skin tone by either experts or by multicultural audience members and employing overall ratings to divide data on coverage into groups by the skin 
tone for further statistical analysis. This will allow generalizing conclusions about media coverage of celebrity capital to the population of actors of color.

\subsection{Study Limitations}

One of the main limitations of this study is a simplified approach to operationalizing such complex concepts as racial and social capital. Some might rightfully argue that choosing two actresses for this pilot study based on the actresses' skin tone is in itself an act of colorism. In addition, racial capital as a separate category in celebrity's capital might be seen as artificial as it has to do with both cultural and social capital. Those decisions were needed for the purposes of coding for manifested content to obtain quantified data on elements of capital because we aimed to establish causal relationships with skin tone and ultimately draw conclusions about colorism in media coverage of celebrities. While we attempted to compensate by providing context with qualitative data analysis, nonetheless, improvements in quantitative measurement of individual's capital are needed.

\subsection{Significance of Research in Colorism}

What makes the current research so crucial is that it provides evidence of societal stratification based on racial measures of skin tone within the entertainment industry. Colorism, deep rooted stereotypes of African American and ideals of white beauty continue to divide the African American community in ways that confound the establishment of a fair and unbiased society. Colorism also has a profound effect on the lives of adolescents and very young children of color as they are exposed to the ideologies concerning skin tone, race, and privilege. There is a need for unity between African-American women of all complexions. However, it is imperative that research begin to elucidate and investigate issues that affect our community, but are not recognized by mainstream society. It is hoped that the results of this study will enrich the body of knowledge on the subject of colorism and women of color, and question the acceptance of colorism formed within Hollywood and the media. Colorism is a multidimensional sociological and psychological phenomenon and more empirical studies of skin tone bias are critical to understanding the internal and external racial conflicts that continue to exist in our society.

\subsection{Future Directions}

Future experimental and longitudinal studies are necessary in order to infer causality between colorism and the effects of it on an actor's credibility and starring versus minor role appearances in movies and on television. Measuring changes in coverage over time might provide insights into how the coverage actors of varying skin tone changes and what are the factors contributing to these changes. Some of the factors might be explained by the characters these actors embody in the movies. It is important that future studies measure skin tone and its relationship to media attention and decisions made in Hollywood based on 
skin tone. Take, for example, the controversial Nina Simone biopic starring Zoe Saldana that was released in 2016. With the debut comes controversy, conflict, and intense debate about colorism and representation because of the decision to cast actor Zoe Saldana in the leading role. Saldana, who is of Dominican and Puerto Rican heritage but also identifies as black, was chosen over several other qualified actresses who better resemble the dark-skinned singer, Nina Simone. When it was revealed that Saldana would be performing the role in makeup in order to darken her skin and would need prosthetics to broaden her features, the backlash on social media was swift and loud. Is it possible that the choice to cast Zoe Saldana, a light-skinned woman of color in the role of Nina Simone was made by those individuals in Hollywood who make little to no attempts to understand the complexities of colorism in the African American community? Future research might survey and interview decision makers in the entertainment industry and gauge their attitudes and biases toward light-skinned versus darkskinned actors. These future directions are important for better understanding the role of Hollywood's social constructions of skin tone across gender as it is a much understudied but important topic.

\section{References}

Arogundade, B. (2014). Black Beauty: A History of the Black Aesthetic, from Antiquity to the Present (3rd ed.). Philadelphia, PA: Running Press.

Barron, J. (1994). Dueling Magazine Covers: A Police Photo vs. a "Photo-Illustration"(p. 8). The New York Times, Section 1.

http://www.nytimes.com/1994/06/21/nyregion/dueling-magazine-covers-a-police-phot o-vs-a-photo-illustration.html

Bourdieu, R. (1986). The Forms of Capital. In J. G. Richardson (Ed.), Handbook of Theory and Research for the Sociology of Education (pp. 241-258). New York, NY: Greenwood Press.

Braddock, J. H., \& McPartland, J. M. (1987). How Minorities Continue to Be Excluded from Equal Employment Opportunities: Research on Labor Market and Institutional Barriers. Journal of Social Issues, 43, 5-39. https://doi.org/10.1111/j.1540-4560.1987.tb02329.x

Bradt, S. (2010). One-Drop Rule Persists: Biracials Viewed as Members of Their Lower-Status Parent Group. http://news.harvard.edu/gazette/story/2010/12/one-drop-rule-persists/

Bridges, W. P., \& Villemez, W. J. (1986). Informal Hiring and Income in the Labor Market. American Sociological Review, 51, 574-582. https://doi.org/10.2307/2095589

Conrad, K., Dixon, T. L., \& Zhang, Y. (2009). Controversial Rap Themes, Gender Portrayals and Skin Tone Distortion: A Content Analysis of Rap Music Videos. Journal of Broadcasting \& Electronic Media, 53, 134-156. https://doi.org/10.1080/08838150802643795

Dion, K., Berscheid, E., \& Walster, E. (1972). What Is Beautiful Is Good. Journal of Personality and Social Psychology, 24, 285-290. https://doi.org/10.1037/h0033731

Driessens, O. (2013). Celebrity Capital: Redefining Celebrity Using Field Theory. Theory and Society, 42, 543-560. https://doi.org/10.1007/s11186-013-9202-3 
Ducille, A. (1996). Skin Trade. Cambridge, MA: Harvard University Press.

Faul, F., Erdfelder, E., Lang, A.-G., \& Buchner, A. (2007). G Power 3: A Flexible Statistical Power Analysis Program for the Social, Behavioral, and Biomedical Sciences. Behavior Research Methods, 39, 175-191. https://doi.org/10.3758/BF03193146

Glenn, E. N. (2008). Yearning for Lightness Transnational Circuits in the Marketing and Consumption of Skin Lighteners. Gender \& Society, 22, 281-302. https://doi.org/10.1177/0891243208316089

Hunter, M. (2004). Light, Bright, and Almost White: The Advantages and Disadvantages of Light Skin. In C. Herring, V. M. Keith, \& H. D. Horton (Eds.), Skin/Deep: How Race and Complexion Matter in the "Color-Blind" Era (pp. 22-44). University of Illinois Press.

Hunter, M. (2007). The Persistent Problem of Colorism: Skin Tone, Status, and Inequality. Sociology Compass, 1, 237-254. https://doi.org/10.1111/j.1751-9020.2007.00006.x

Kurtz, H. (1994). Time’s “Sinister” Simpson Cover Photo Was Computer Enhanced(D1). The Washington Post.

Lipsitz, G. (1997). The Greatest Story Ever Sold: Marketing and the O. J. Simpson Trial. In T. Morrison, \& C. B. Lacour (Eds.), Birth of a Nation Hood: Gaze, Script, and the Spectacle in the O. J. Simpson Case. New York, NY: Pantheon Books.

Marsden, P. V., \& Hurlbert, J. S. (1988). Social Resources and Mobility Outcomes: A Replication and Extension. Social Forces, 66, 1038-1059.

https://doi.org/10.2307/2579435

McLoughlin, L. (2013). Crystal Clear: Paler Skin Equals Beauty-A Multimodal Analysis of Asiana Magazine. South Asian Popular Culture, 11, 15-29. https://doi.org/10.1080/14746689.2013.764639

Molina-Guzmán, I. (2013). Commodifying Black Latinidad in US Film and Television. Popular Communication, 11, 211-226. https://doi.org/10.1080/15405702.2013.810071

Neal, A. M., \& Wilson, M. L. (1989). The Role of Skin Color and Features in the Black Community: Implications for Black Women and Therapy. Clinical Psychology Review, 9, 323-333.

Parameswaran, R., \& Cardoza, K. (2009). Melanin on the Margins: Advertising and the Cultural Politics of Fair/Light/White Beauty in India. Journalism \& Communication Monographs, 11, 213-274. https://doi.org/10.1177/152263790901100302

Pasco, R. J. (2003). Capital and Opportunity: A Critical Ethnography of Students At-Risk. University Press of America.

Portes, A. (1998). Social Capital: Its Origins and Applications in Modern Society. Annual Reviews of Sociology, 24, 1-24. https://doi.org/10.1146/annurev.soc.24.1.1

Rockquemore, K. A., \& Brunsma, D. L. (2004). Beyond Black? The Reflexivity of Appearances in Racial Identification among Black/White Biracials. In C. Herring, V. M. Keith, \& H. D. Horton (Eds.), Skin/Deep: How Race and Complexion Matter in the “Color-Blind” Era (pp. 99-127). University of Illinois Press.

Russell, K., Wilson, M., \& Hall, R. (1992). The Color Complex: The Politics of Skin Color among African Americans. New York, NY: Harcourt Brace Jovanovich.

Strauss, A., \& Corbin, J. (1998). Basics of Qualitative Research: Procedures and Techniques for Developing Grounded Theory. Thousand Oaks, CA: Sage.

Thompson, M. S., \& Keith, V. M. (2001). The Blacker the Berry: Gender, Skin Tone, 
Self-Esteem, and Self-Efficacy. Gender and Society, 15, 336-357. https://doi.org/10.1177/089124301015003002

Tomaskovic-Devey, D., Zimmer, C., Stainback, K., Robinson, C., Taylor, T., \& McTague, T. (2006). Documenting Desegregation: Segregation in American Workplaces by Race, Ethnicity, and Sex, 1966-2003. American Sociological Review, 71, 565-588. https://doi.org/10.1177/000312240607100403

White, S. B. (2005). Releasing the Pursuit of Bouncin' and Behavin' Hair: Natural Hair as an Afrocentric Feminist Aesthetic for Beauty. International Journal of Media and Cultural Politics, 1, 295-308. https://doi.org/10.1386/macp.1.3.295/1

Van Riper, F. (1994). The Negatives of Fakery(N56). The Washington Post.

Volz, Y. Z., \& Lee, F. L. (2013a). What Does It Take for Women Journalists to Gain Professional Recognition? Gender Disparities among Pulitzer Prize Winners, 1917-2010. Journalism \& Mass Communication Quarterly, 90, 248-266. https://doi.org/10.1177/1077699013482908

Volz, Y. Z., \& Lee, F. L. (2013b). Who Wins the Pulitzer Prize in International Reporting? Cumulative Advantage and Social Stratification in Journalism. Journalism, 14, 587-605. https://doi.org/10.1177/1464884912455905

Submit or recommend next manuscript to SCIRP and we will provide best service for you:

Accepting pre-submission inquiries through Email, Facebook, LinkedIn, Twitter, etc. A wide selection of journals (inclusive of 9 subjects, more than 200 journals) Providing 24-hour high-quality service User-friendly online submission system Fair and swift peer-review system Efficient typesetting and proofreading procedure Display of the result of downloads and visits, as well as the number of cited articles Maximum dissemination of your research work

Submit your manuscript at: http://papersubmission.scirp.org/

Or contact ajc@scirp.org 